\title{
UPAYA MENINGKATKAN HASIL BELAJAR PKn MELALUI MODEL PEMBELAJARAN SCRAMBLE SISWA DI SDN 13 MUARA KUANG
}

Article info

Article history:

Received: $10 / 05 / 2019$

Revised : 11/05/2019

Accepted: 12/06/2019

Keywords:

learning outcomes,

Civics, scramble

models

Kata Kunci: hasil

belajar, PKn,model

scramble

\author{
Samsidar \\ Guru SD Negeri 13 Muarakuang \\ Desa Muarakuang Kab. Ogan Ilir Sumsel \\ Sur-el: samsidar.sdn13mk@gmail.com
}

\begin{abstract}
A B S T R A C T
The research subjects were grade V students of SD Negeri 13 Muara Kuang, totaling 17 students. Methods of data collection in the form of tests, observations, and documentation. The data analysis technique used is descriptive quantitative and qualitative. The indicators of the success of the action are marked by $75 \%$ of the number of students who take part in the learning process that have obtained KKM scores. Based on the results of the tests in the implementation of learning with a scramble model, students who achieved a value of $\geq 75$ were $70.59 \%$ in the first cycle and increased to $88.24 \%$ in the second cycle. The action was dismissed in the second cycle because it had reached the criteria of success.
\end{abstract}

Penelitian tindakan kelas ini bertujuan meningkatkan hasil belajar PKn (Pendidikan Kewarganegaraan) dengan model scramble. Subjek penelitian adalah siswa kelas V SD Negeri Negeri 13 Muara Kuang, berjumlah 17 siswa. Metode pengumpulan data berupa tes, observasi, dan dokumentasi. Teknik analisis data yang digunakan adalah deskriptif kuantitatif dan kualitatif. Adapun indikator keberhasilan tindakan ditandai dengan $75 \%$ dari jumlah siswa yang mengikuti proses pembelajaran telah memperoleh nilai KKM. Hasil penelitian menunjukkan adanya peningkatan. Berdasarkan hasil tes dalam pelaksanaan pembelajaran dengan model scramble, siswa yang mencapai nilai $\geq 75$ sebesar $70,59 \%$ pada siklus I dan meningkat menjadi 88,24\% pada siklus II. Peningkatan hasil belajar tersebut terjadi setelah adanya perbaikan tindakan pada siklus II yaitu guru membagi kelompok menjadi lebih jelas, anggota kelompok diperkecil jumlahnya, dan pemberian reward kepada siswa yang tenang. Tindakan diberhentikan pada siklus II karena telah mencapai kriteria keberhasilan. 


\section{JURNAL ILMIAH \\ BINA EDUKASI \\ ISSN 1979-8598 e-ISSN: 2655-8378 \\ http://journal.binadarma.ac.id/index.php/jurnalbinaedukasi \\ Vol. 12, No. 1, Juni 2019, 16-30}

\section{PENDAHULUAN}

Mata pelajaran yang memiliki durasi 2 jam pelajaran dalam seminggu yaitu PKn. Mata pelajaran PKn mempunyai waktu yang paling pendek daripada mata pelajaran yang lain. PKn merupakan mata pelajaran yang membahas tentang pengembangan kemampuan peserta didik agar dapat tumbuh menjadi warga negara yang baik (good citizen). Salah satu aspek yang dibahas dalam Pendidikan Kewarganegaraan yaitu tentang cara berpikir kritis dan kreatif. Hal tersebut didukung dengan pernyataan yang disampaikan oleh Badan Standar Nasional Pendidikan (BSNP) bahwa salah satu tujuan mata pelajaran PKn yaitu memberikan kompetensikompetensi kepada siswa agar mampu berpikir secara kritis, rasional, dan kreatif dalam menanggapi isu kewarganegaraan. Siswa diberi kesempatan untuk berpikir dengan baik dalam menyatakan pendapatnya terhadap masalah kewarganegaraan.

Sunarso (2006:14) kompetensi adalah seperangkat tindakan cerdas, penuh tanggung jawab, yang harus dimiliki oleh seseorang sebagai syarat untuk dapat dianggap mampu melakukan tugas-tugas dalam bidang pekerjaan tertentu. Kompetensi merupakan ketentuan yang ditetapkan oleh seseorang atau lembaga agar dapat menyelesaikan tugas sesuai dengan ranah ilmu yang sedang dipelajari.

Muslich (2007:91) menyatakan bahwa penilaian pembelajaran berbasis kompetensi pada KTSP menggunakan Penilaian Berbasis Kelas (PBK). PKB muncul berdasarkan kegiatan yang dilaksanakan secara terpadu dalam proses pembelajaran. PBK diterapkan dalam tiga ranah yaitu ranah pengetahuan (kognitif), ranah sikap (afektif), dan ranah keterampilan (psikomotor). Sehingga siswa diharapkan untuk mencapai ketiga ranah tersebut dalam proses pembelajaran dalam mencapai hasil belajar yang maksimal. Purwanto (2009:38-39) juga menyatakan bahwa belajar merupakan proses dalam diri individu yang berinteraksi dengan lingkungan untuk mendapatkan perubahan dalam perilakunya.

Oleh karena itu, Selain kompetensi, kinerja guru juga bisa menjadi pengaruh terhadap hasil belajar siswa. Sebagai seorang pendidik, guru bertugas sebagai penyalur pengetahuan kepada siswa saat proses pembelajaran berlangsung. Selain itu, menurut Sugiyanto (2009:1) menyatakan bahwa profesionalisme seorang guru bukanlah pada kemampuannya mengembangkan ilmu pengetahuan, tetapi lebih pada kemampuannya untuk melaksanakan pembelajaran yang menarik dan bermakna bagi siswa. Berdasarkan pernyataan tersebut guru perlu memberikan inovasi dalam proses pembelajaran di kelas. Inovasi yang perlu dilakukan guru salah satunya yakni menggunakan model pembelajaran. 


\section{JURNAL ILMIAH \\ BINA EDUKASI \\ ISSN 1979-8598 e-ISSN: $2655-8378$ \\ http://journal.binadarma.ac.id/index.php/jurnalbinaedukasi \\ Vol. 12, No. 1, Juni 2019, 16-30}

Berdasarkan pengamatan yang dilakukan di kelas V SD Negeri 13 Muara Kuang menunjukkan bahwa pada proses pembelajaran PKn, siswa dituntut untuk mencatat materi, mengerjakan LKS, atau mengerjakan soal dari guru. Kegiatan-kegiatan tersebut belum membuat siswa dapat berpikir kritis dan kreatif sesuai dengan tujuan pada pembelajaran PKn. Padahal mata pelajaran PKn membutuhkan pemahaman materi dengan baik karena luasnya kompetensi yang dipelajari oleh siswa. Maka, siswa perlu diberikan kesempatan untuk menggunakan model pembelajaran yang lain pada proses pembelajaran PKn.

Salah satu model pembelajaran yang dapat memperbaiki proses pembelajaran PKn di kelas V SD Negeri 13 Muara Kuang yakni menggunakan model pembelajaran scramble. Menurut Shoimin (2016: 166) melalui pembelajaran model pembelajaran scramble siswa dapat dilatih berkreasi menyusun kata, kalimat, atau wacana yang acak susunannya dengan susunan yang bermakna dan mungkin lebih baik dari susunan aslinya. Kegiatan menyusun kata, kalimat, atau wacana dapat memperluas pengetahuan siswa, sehingga dapat mengingat berbagai kosakata.

Uraian latar belakang di atas menunjukkan permasalahan yang terjadi pada siswa, guru, dan hasil belajar PKn di Kelas V SD Negeri 13 Muara Kuang. Oleh karena itu, peneliti mengkaji penelitian ini.

\section{METODOLOGI PENELITIAN}

\subsection{Jenis Penelitian}

Jenis penelitian yang digunakan dalam penelitian ini yakni Penelitian Tindakan Kelas (PTK). Arikunto (2015:1) menjelaskan bahwa penelitian tindakan kelas adalah penelitian yang memaparkan terjadinya sebab-akibat dari perlakuan, sekaligus memaparkan apa saja yang terjadi ketika perlakuan diberikan, dan memaparkan seluruh proses sejak awal pemberian perlakuan sampai dengan dampak dari perlakuan tersebut.

\subsection{Subjek Penelitian}

Subjek penelitian ini adalah siswa kelas V SD Negeri 13 Muara Kuang Kecamatan Muara Kuang Kabupaten Ogan Ilir tahun pelajaran 2018/2019. Jumlah siswa yaitu 17 siswa yang terdiri dari 5 siswa perempuan dan 12 siswa laki-laki. 


\subsection{Setting Penelitian}

Penelitian ini dilaksanakan pada siswa kelas V SD Negeri 13 Muara Kuang Semester II tahun ajaran 2018/2019.

\subsection{Desain Penelitian}

\section{1) Rancangan Penelitian}

Berdasarkan jenis penelitian yang dipilih, yaitu penelitian tindakan kelas maka, dalam penelitian ini peneliti menggunakan model penelitian tindakan dari Kemmis dan Taggart yang berbentuk spiral, model penelitian ini saling terkait dari siklus satu ke siklus berikutnya. Berdasarkan Arikunto (2006: 98) menyebutkan bahwa secara utuh, tindakan yang diterapkan dalam penelitian tindakan kelas yakni terdapat 4 tahapan secara berurutan yaitu, tahap menyusun rancangan tindakan dan dikenal dengan perencanaan, tahap pelaksanaan tindakan, tahap pengamatan, dan terakhir tahap refleksi atau pantulan.

\section{2) Rancangan Tindakan}

\section{A. Pra siklus}

Pada tahap ini peneliti melakukan observasi dan dokumentasi terhadap kegiatan belajar mengajar siswa di kelas V SD Negeri 13 Muara Kuang yang digunakan sebagai acuan untuk membuat perencanaan tindakan. Setelah pembelajaran selesai, peneliti melakukan wawancara terhadap guru kelas tentang hasil belajar PKn siswa kelas V SD Negeri 13 Muara Kuang. Berdasarkan data yang diperoleh, kemudian dilakukan identifikasi bahwa hasil belajar PKn siswa kelas V SD Negeri 13 Muara Kuang masih rendah, sehingga dibutuhkan model pembelajaran atau tindakan guru dalam mengatasi masalah tersebut. Peneliti dan guru mendiskusikan model yang akan digunakan untuk meningkatkan hasil belajar siswa, yaitu model pembelajaran scramble.

\section{B. Siklus I}

\section{i) Perencanaan}

a. Peneliti bersama guru menetapkan penggunaan model pembelajaran scramble untuk meningkatkan hasil belajar PKn siswa kelas V SD Negeri 13 Muara Kuang. 


\section{JURNAL ILMIAH \\ BINA EDUKASI \\ ISSN 1979-8598 e-ISSN: 2655-8378 \\ http://journal.binadarma.ac.id/index.php/jurnalbinaedukasi \\ Vol. 12, No. 1, Juni 2019, 16-30}

b. Peneliti dan guru menentukan materi pokok bahasan, kompetensi dasar, serta membuat indikator-indikator sesuai kompetensi dasar tersebut.

c. Peneliti menyusun skenario pembelajaran atau rencana pelaksanaan pembelajaran (RPP) dengan persetujuan dosen pembimbign dan juga guru yang bersangkutan.

d. Peneliti mempersiapkan sumber belajar (materi) dan bahan (alat pembelajaran) yang akan digunakan dalam proses belajar mengajar.

e. Peneliti menyiapkan instrumen yang akan digunakan yaitu lembar observasi dan soal tes.

ii)Tindakan dan pengamatan

Tahap ini merupakan tahap dilaksanakannya tindakan. Tindakan dilakukan oleh guru kelas dalam proses pembelajaran sesuai dengan RPP yang telah dibuat menggunakan model pembelajaran scramble. Peneliti mengamati jalannya pelaksanaan tindakan yang dilaksanakan oleh guru tersebut. Tindakan yang dilaksanakan dalam proses pembelajaran dengan menggunakan model pembelajaran scramble adalah sebagai berikut:

a) Guru membuka pelajaran dengan mengucapkan salam dan mengajak seluruh siswa berdo'a.

b) Guru melakukan apersepsi yang berhubungan dengan materi pelajaran mengenai keputusan bersama.

c) Guru menyampaikan tujuan pembelajaran yang akan dicapai dari proses pembelajaran yang akan berlangsung.

d) Guru memberikan materi yang akan dipelajari.

e) Guru membagi siswa dalam kelompok kecil dan memberikan Lembar Kerja Siswa (LKS) pada masing-masing kelompok tersebut.

f) Guru meminta siswa untuk membaca aturan pelaksanaan.

g) Guru mengamati diskusi siswa dalam mengerjakan LKS.

h) Setelah selesai, siswa melakukan presentasi di depan kelas.

i) Guru dan siswa membahas tugas yang telah dikerjakan.

j) Guru memberikan kesempatan kepada siswa untuk bertanya tentang materi yang sudah dipelajari.

k) Guru dan siswa menyimpulkan pembelajaran.

Selama proses pembelajaran berlangsung, peneliti melakukan pengamatan (observasi) dengan rekan peneliti yang diperlukan sebagai bahan refleksi atau evaluasi agar pembelajaran yang berlangsung lebih baik dan mencapai tujuan pembelajaran . 


\section{JURNAL ILMIAH \\ BINA EDUKASI \\ ISSN 1979-8598 e-ISSN: $2655-8378$ \\ http://journal.binadarma.ac.id/index.php/jurnalbinaedukasi \\ Vol. 12, No. 1, Juni 2019, 16-30}

iii) Refleksi

Pelaksanaan refleksi berupa diskusi antara peneliti, observer, dan guru kelas V SD Negeri 13 Muara Kuang. Diskusi dilaksanakan bertujuan untuk mengkaji secara menyeluruh terhadap data dari lembar observasi. Hasil refleksi ini digunakan sebagai acuan dalam membuat rencana perbaikan pada siklus berikutnya.

\section{Siklus II}

Siklus II dilaksanakan apabila pembelajaran yang dilakukan pada siklus I belum sesuai dengan indikator ketercapaian yang ditentukan, yaitu minimal $75 \%$ dari jumlah siswa pada kategori baik dan sangat baik. Apabila siklus II belum berhasil, maka dilanjutkan dengan siklus berikutnya.

\subsection{Kriteria Keberhasilan}

KKM yang diterapkan pada SD Negeri 13 Muara Kuang adalah 75. Siswa dikatakan tuntas dalam pembelajaran apabila mencapai nilai 75. Penelitian tindakan kelas ini dikatakan berhasil apabila pembelajaran dengan menggunakan model pembelajaran scramble dikatakan dapat meningkatkan hasil belajar PKn pada siswa kelas V SD Negeri 13 Muara Kuang apabila minimal 75\% dari jumlah siswa mencapai KKM yaitu 75 .

\section{HASIL DAN PEMBAHASAN}

\subsection{Hasil Tes Awal}

Sebelum tindakan penelitian dilaksanakan, terlebih dahulu dilakukan tes awal pada hari Rabu, 06 Februari 2019 dari pukul 07.30 sampai dengan 08.05 tes awal dilaksanakan selama satu jam pelajaran atau 35 menit dengan memberikan tes awal untuk mengetahui hasil belajar siswa kelas V SD Negeri 13 Muara Kuang. Tujuan pelaksanaan tes awal ini untuk mendapatkan bahan masukan sebagai dasar pertimbangan dalam menyusun perencanaan, tindakan, observasi dan refleksi siklus 1 .

Berdasarkan hasil belajar siswa diketahui bahwa dari 17 orang siswa, ada 2 orang siswa yang mencapai nilai KKM. Rata-rata nilai untuk tes awal dalam menjawab pertanyaan seputar 


\section{JURNAL ILMIAH}

BINA EDUKASI

ISSN 1979-8598 e-ISSN: 2655-8378

http://journal.binadarma.ac.id/index.php/jurnalbinaedukasi

Vol. 12, No. 1, Juni 2019, 16-30

luas persegi dan persegi panjang adalah 50,59. Selanjutnya adalah 15 orang yang belum mencapai KKM artinya ketuntasan yang dicapai pada tes awal adalah 11,76\%.

Hasil nilai tes awal berdasarkan nilai tertinggi, terendah, dan rata-rata dapat diketahui pada tabel berikut:

Tabel 1. Nilai Hasil Tes Awal Materi

\begin{tabular}{ccccc}
\hline No & Skor & F & $\begin{array}{c}\text { Kelas V } \\
\text { Presentase Ketuntasan }\end{array}$ \\
\hline 1 & $>80$ & 0 & 0 \\
2 & $71-80$ & 2 & 11,76 \\
3 & $61-70$ & 3 & 17,65 \\
4 & $51-60$ & 1 & & 17,89 \\
5 & $41-50$ & 3 & & 47,05 \\
6 & $<40$ & 8 & 50,59 & \\
& Nilai rata-rata & & 17 \\
\hline
\end{tabular}

Berdasarkan tabel diatas dapat diketahui bahwa nilai tertinggi adalah 80 , nilai terendah adalah 25, dan nilai rata-rata adalah 50,59. Dari jumlah siswa 17 orang, ada 2 orang yang mendapat nilai antara 71-80, 3 orang siswa mencapai nilai 61-70, 1 orang siswa mencapai nilai 51-60, 3 orang siswa mencapai nilai 41-50 dan 8 orang siswa mendapat nilai antara $<40$.

\subsection{Hasil Penelitian Siklus I}

\section{a. Deskripsi Tindakan dan Pengamatan Siklus I Pembelajaran Ke-I}

Peneliti dalam hal ini selaku guru, masuk ke kelas V bersama dengan Ibu Ernawati, S.Pd sebagai kolabolator. Guru menempati kursi dan meja guru yang berada didepan kelas, sedangkan rekan kolabolator mengambil tempat dibelakang. Guru mengabsensi siswa satu persatu. Hari itu semua siswa kelas V hadir.

Pelaksanaan tindakan siklus I pertemuan 1 dilaksanakan pada hari Rabu, 6 Februari 2019 pukul 09.50-11.00. Deskripsi pelaksanaan kegiatannya adalah sebagai berikut:

Guru menyampaikan tujuan pembelajaran pada hari itu, yaitu setelah kegiatan belajarmengajar siswa dapat menjawab pertanyaan yang berkaitan dengan menggunakan metode Scramble.

Sebelum masuk ke contoh soal, guru terlebih dahulu menjelaskan tentang materi PKn Saat guru menjelaskan, guru menunjuk siswa untuk memberikan contoh dari materi yang diberikan. 


\section{JURNAL ILMIAH \\ BINA EDUKASI \\ ISSN 1979-8598 e-ISSN: $2655-8378$ \\ http://journal.binadarma.ac.id/index.php/jurnalbinaedukasi \\ Vol. 12, No. 1, Juni 2019, 16-30}

Selanjunya Guru mempersiapkan kartu/lembar soal dan kartu/lembar jawab yang sudah diacak jawabannya. Siswa mendengarkan materi yang disampaikan guru tentang keputusan bersama. Setelah siswa paham, guru membagi siswa menjadi 4 kelompok serta diberi kartu/lembar soal dan lembar/kartu jawaban yang diacak jawabannya.

Setelah semua kelompok mendapatkan lembar kerja siswa (LKS), masing-masing kelompok mengerjakan dengan baik namun guru belum memberi durasi waktu pengerjaan kepada siswa. Ada beberapa siswa yang bertanya tentang bagaimana cara pengerjaan LKS yang diberikan oleh guru. Guru menjawab pertanyaan siswa apabila masih bingung. Siswa bekerja sama dalam kelompok sedangkan guru mengecek pekerjaan siswa dengan memeriksa setiap kelompok. Karena tidak diberi durasi waktu, guru tidak memeriksa waktu dan tidak memeriksa pekerjaan setiap kelompok. Siswa hanya diminta untuk mengumpulkan hasil pekerjaannya menjelang waktu pembelajaran PKn hampir selesai. Setiap kelompok, sebagian besar masih belum bisa mengerjakan semua soal karena baru saja mengerjakan soal dengan model baru. Guru bersama siswa mencocokkan pekerjaan siswa jika semua kelompok sudah mengumpulkan LKS.

Pada siklus pertemuan awal ini guru belum memberikan apresiasi kepada kelompok yang sudah menjawab dengan benar dan belum memberi semangat kepada kelompok yang belum cukup berhasil dalam mengerjakan tugas karena terkendala waktu. Guru belum memberikan kegiatan pengayaan berupa pemberian tugas kepada siswa. Guru juga belum memberikan koreksi pada pembelajaran hari itu dan menyimpulkan pembelajaran yang sudah dilakukan.

Kemudian Guru membimbing siswa kembali ke tempat duduk masing-masing. Sebelum memberikan nasehat kepada siswa agar selalu memikirkan keputusan yang akan dibuat secara matang. Guru mengakhiri kegiatan pembelajaran dengan salam penutup

\section{Deskripsi Tindakan dan Pengamatan Siklus I Pembelajaran ke-2}

Pelaksanaan tindakan siklus I pertemuan 2 dilaksanakan pada hari Rabu, 10 Mei 2017 pukul 09.50-11.00. Deskripsi pelaksanaan kegiatannya sebagai berikut:

Pada pertemuan kedua, guru sudah memberi durasi waktu pengerjaan kepada siswa. Siswa bekerja sama dalam kelompok dengan baik. Pengecekan waktu oleh guru belum dilaksanakan sehingga banyak siswa yang ramai dan pengerjaan soal belum maksimal. Jika waktu sudah selesai, maka LKS dikumpulkan kepada guru. Guru bersama siswa mencocokkan pekerjaan siswa jika semua kelompok sudah mengumpulkan LKS. Pada pertemuan 2, guru sudah memberi apresiasi kepada kelompok yang sudah menjawab dengan benar dan memberi 


\section{JURNAL ILMIAH}

BINA EDUKASI

ISSN 1979-8598 e-ISSN: $2655-8378$

http://journal.binadarma.ac.id/index.php/jurnalbinaedukasi

Vol. 12, No. 1, Juni 2019, 16-30

semangat kepada kelompok yang belum cukup berhasil dalam mengerjakan tugas. Guru juga sudah memberikan kegiatan pengayaan berupa pemberian tugas kepada siswa berupa membuat kartu soal dan kartu jawab untuk dibawa pada pertemuan berikutnya. Kemudian siswa bersama guru memberikan koreksi pada pembelajaran hari itu dan menyimpulkan pembelajaran yang sudah dilakukan.

Data Nilai hasil Belajar dari Siklus I dapat diketahui bahwa dari 17 orang siswa, ada 12 orang siswa yang mencapai nilai KKM. Rata-rata nilai untuk tes awal adalah 50,59. Selanjutnya ada 5 orang yang belum mencapai KKM artinya ketuntasan yang dicapai pada tes awal adalah $29,41 \%$.

\section{Tahap Observasi}

Dari hasil pengamatan yang dilakukan oleh peneliti menunjukkan bahwa pembelajaran PKn pada siklus I berjalan dengan baik meskipun hasil belajar yang diperoleh belum semua siswa mencapai KKM, sehingga perlu dilanjutkan siklus berikutnya. Observasi ini dilakukan terhadap aktivitas guru yang dilakukan dalam dua pertemuan, yaitu pertemuan 1 dan pertemuan 2.

\section{Tahap Refleksi}

Tahap ke empat atau terakhir dari penelitian tindakan kelas adalah refleksi. Kegiatan refleksi bertujuan untuk mengemukakan kembali berbagai hal yang telah terjadi pada saat pelaksanaan tindakan. Pelaksanaan refleksi dilakukan pada akhir siklus I oleh peneliti dan guru. Hal ini peneliti lakukan untuk mengetahui apakah penerapan model pembelajaran scramble pada mata pelajaran PKn pada siklus I dapat meningkatkan hasil belajar siswa dari aspek kognitif. Setelah mengetahui beberpa hambatan atau permasalahan tersebut yang menjadi penyebab ketidakberhasilan pelaksanaan tindakan siklus I, selanjutnya peneliti dan guru menyusun rencana perbaikan untuk melaksanakan penelitian pada siklus II.

\section{b. Pelaksanaan Tindakan Siklus II Pertemuan 1}

\section{(1) Kegiatan Awal}

Pada kegiatan awal guru mengkondisikan siswa agar siap mengikuti pelajaran. Guru menunjuk salah satu siswa untuk memimpin doa. Guru melakukan presensi terhadap kehadiran siswa dan melakukan apersepsi. Lalu guru menyampaikan tujuan pembelajaran. Pada siklus II, guru mulai mengajak siswa membuat kesepakatan bahwa siswa yang tenang akan mendapat stiker bintang. 


\section{JURNAL ILMIAH \\ BINA EDUKASI \\ ISSN 1979-8598 e-ISSN: 2655-8378 \\ http://journal.binadarma.ac.id/index.php/jurnalbinaedukasi \\ Vol. 12, No. 1, Juni 2019, 16-30}

(2) Kegiatan inti

Pada pertemuan 1 di siklus II guru sudah menyiapkan lembar soal dan lembar jawab yang sudah diacak jawabannya dengan baik. Siswa mendengarkan materi yang disampaikan guru untuk materi keputusan bersama. Karena ada perbaikan di siklus I ke siklus II, maka guru membagi siswa menjadi 6 kelompok serta diberi kartu/lembar soal dan lembar/kartu jawaban yang diacak jawabannya.

Namun siswa hanya membentuk 5 kelompok saja. Guru tidak memberi waktu pengerjaan soal kepada siswa karena siswa masih ramai menata kelompok. Guru langsung membagikan lembar soal dan lembar jawab yang disiapkan sebelumnya. Guru mengecek pekerjaan siswa dengan berkeliling kelas. Ada beberapa kelompok yang belum selesai mengerjakan soal saat guru meminta setiap kelompok mengumpulkan hasil pekerjaannya. Guru bersama siswa mencocokkan pekerjaan siswa jika semua kelompok sudah mengumpulkan LKS. Kemudian guru memberi apresiasi kepada kelompok yang sudah menjawab dengan benar dan memberi semangat kepada kelompok yang belum cukup berhasil dalam mengerjakan tugas.

Guru memberikan kegiatan pengayaan berupa pemberian tugas kepada siswa. Setelah kegiatan tersebut selesai, kemudian siswa bersama guru memberikan koreksi pada pembelajaran hari itu dan menyimpulkan pembelajaran yang sudah dilakukan.

(3) Kegiatan akhir

Guru membimbing siswa kembali ke tempat duduk masing-masing. Guru membagi stiker bintang kepada siswa yang tenang.

Guru hanya memberi stiker bintang kepada beberapa siswa yang tenag saat pembelajaran. Sebelum menutup pembelajaran, guru menyampaikan pesan kepada siswa agar dapat memahami dengan baik bentuk-bentuk keputusan bersama dan pertemuan yang akan datang semua siswa akan diberikan stiker bintang apabila patuh pada perintah guru. Guru mengakhiri kegiatan pembelajaran dengan salam penutup.

\section{Pelaksanaan Tindakan Siklus II Pertemuan 2}

(1) Kegiatan Awal

Pada kegiatan awal guru mengkondisikan siswa agar siap mengikuti pelajaran. Guru menunjuk salah satu siswa untuk memimpin berdo'a. Guru melakukan presensi terhadap kehadiran siswa. Guru melakukan apersepsi yaitu "pada tahun 2014 Indonesia mengadakan 


\section{JURNAL ILMIAH \\ BINA EDUKASI \\ ISSN 1979-8598 e-ISSN: $2655-8378$ \\ http://journal.binadarma.ac.id/index.php/jurnalbinaedukasi \\ Vol. 12, No. 1, Juni 2019, 16-30}

pemilihan presiden. Terpilihlah Joko Widodo menjadi presiden. Banyak dukungan bahkan menyayangkan terpilihnya presiden yang baru. Sikap mana yang lebih baik?". Siswa menanggapi apersepsi guru dengan menjawab "sebaiknya mendukung dan menerima dengan keputusan yang sudah terjadi”. Kemudian guru menjelaskan bahwa dalam keputusan bersama pasti ada perbedaan pendapat antar anggota. Guru menjelaskan tujuan pembelajaran tentang sikap yang tepat dalam melaksanakan keputusan bersama. Guru juga menyampaikan bahwa apabila semua siswa di kelas tenang dalam proses pembelajaran, guru akan membagikan 2 stiker untuk masing-masing anak.

(2) Kegiatan Inti

Pada saat pembelajaran dimulai, guru sudah mempersiapkan lembar soal dan lembar jawab. Setelah itu guru menyampaikan materi yang disampaikan guru sedangkan siswa mendengarkan. Setelah siswa paham, guru membagi siswa menjadi 6 kelompok dan siswa membentuk kelompok sesuai perintah guru.

Setelah itu guru membagi kartu/lembar soal dan lembar/kartu jawaban yang diacak jawabannya. Guru memberikan durasi waktu pengerjaan soal kepada siswa saat siswa sudah menerima lembar soal dan lembar jawab. Siswa bekerja sama dalam kelompok sedangkan guru mengecek pekerjaan siswa dengan memeriksa setiap kelompok. Jika waktu sudah selesai, maka LKS dikumpulkan kepada guru. Guru bersama siswa mencocokkan pekerjaan siswa jika semua kelompok sudah mengumpulkan LKS. Guru sudah memberi apresiasi kepada kelompok yang sudah menjawab dengan benar dan memberi semangat kepada kelompok yang belum cukup berhasil dalam mengerjakan tugas. Guru memberikan kegiatan pengayaan berupa pemberian soal untuk mengukur seberapa jauh siswa dapat memahami materi pada siklus II. Setelah siswa selesai mengerjakan tugas, kemudian guru bersama siswa memberikan koreksi pada pembelajaran hari itu dan menyimpulkan pembelajaran yang sudah dilakukan.

(3) Kegiatan Akhir

Guru menyampaikan pesan kepada siswa agar dalam melaksanakan keputusan bersama dapat menerapkan sikap yang tepat dan baik. selain itu guru juga memberikan 2 stiker bintang kepada setiap siswa karena sudah berusaha tenang dalam pembelajaran dan patuh pada perintah guru. Kemudian guru mengakhiri kegiatan pembelajaran dengan salam penutup.

\section{3) Tahap Observasi}

Tahap observasi pada siklus II sama seperti pada siklus I. Hasil observasi pada pembelajaran PKn dengan menggunakan model pembelajaran scramble pada siklus II berjalan lebih baik dibandingkan dengan siklus I. Observasi ini dilakukan terhadap aktivitas guru yang 


\section{JURNAL ILMIAH}

BINA EDUKASI

ISSN 1979-8598 e-ISSN: 2655-8378

http://journal.binadarma.ac.id/index.php/jurnalbinaedukasi

Vol. 12, No. 1, Juni 2019, 16-30

dilakukan dalam 2 pertemuan, yaitu pertemuan 1 dan pertemuan 2. Hasil observasi pada siklus II adalah sebagai berikut: a) Keterlaksanaan model pembelajaran scramble.

Pada proses pengamatan guru, pada pembelajaran PKn menggunakan lembar observasi yang telah dipersiapkan. Guru sudah menerapkan aspek-aspek pada model pembelajaran scramble secara menyeluruh. Sehingga siswa mampu melaksanakan aspek-aspek dalam model pembelajaran scramble. Kendala-kendala yang muncul pada siklus I dapat diatasi pada siklus II.

Pada siklus II siswa terlihat lebih tenang dan memahami pembelajaran yang disampaikan guru. Siswa dapat mengerjakan tugas yang diberikan oleh guru dengan baik dan tepat. Hal tersebut dikarenakan siswa diberi waktu lebih lama.

Hasil siklus II berupa rata-rata nilai evaluasi mengalami peningkatan dari siklus I. Berdasarkan hasil pengolahan data dapat diketahui bahwa siswa yang tuntas sebanyak 15 siswa atau sebesar $88,24 \%$, sedangkan siswa yang belum tuntas sebanyak 2 siswa atau sebesar 11,67 $\%$. Rata - rata hasil belajar pada siklus II mencapai 82,94.

Berdasarkan data tabel di atas, dapat disimpulkan bahwa hasil belajar PKn siswa kelas V SD Negeri 13 Muara Kuang pada siklus II mengalami peningkatan dari nilai rata-rata pra siklus dan siklus I. peningkatan nilai rata-rata kelas V pada siklus II sudah sesuai dengan kriteria keberhasilan yang ingin dicapai pada penelitian ini. Berikut tabel perbandingan hasil belajar nilai pra sikus, Siklus I, dan Siklus II.

Tabel 2. Perbandingan Hasil Belajar Nilai Pra Siklus, Siklus I, dan Siklus II

\begin{tabular}{ccccccc}
\hline \multirow{2}{*}{$\begin{array}{c}\text { Kriteria } \\
\text { Ketuntasan }\end{array}$} & \multicolumn{2}{c}{ Nilai Pra Siklus } & \multicolumn{2}{c}{ Nilai Siklus I } & \multicolumn{2}{c}{ Siklus II } \\
& Jumlah & Persen & Jumlah & Persen & Jumlah & Persen \\
\hline Tuntas & 2 & 11,76 & 12 & 70,59 & 15 & 88,24 \\
Belum Tuntas & 15 & 88,24 & 5 & 29,41 & 2 & 11,76 \\
Rata-rata & \multicolumn{2}{c}{50,59} & \multicolumn{2}{c}{68,82} & & \multicolumn{2}{c}{82,94} \\
\hline
\end{tabular}

Data tabel di atas menunjukkan bahwa nilai hasil belajar siswa meningkat dari nilai pra siklus ke siklus I dan siklus II. Siswa yang tuntas pada nilai pra siklus sebanyak 2 siswa atau sebesar $11,76 \%$ menjadi 12 siswa atau sebesar 70,59\% pada siklus I dan mencapai 15 siswa atau $88,24 \%$ pada siklus II. Siswa yang belum tuntas pada nilai pra siklus sebanyak 12 siswa atau 70,59\% menjadi 5 siswa atau sebesar 29,41\% pada siklus I dan mencapai 2 siswa atau 11,76\% pada siklus II. Sedangkan nilai rata-rata pada nilai pra siklus sebesar 50,59 menjadi 68,82 pada siklus I dan mencapai 82,94 pada siklus II.

4) Tahap Refleksi 


\section{JURNAL ILMIAH \\ BINA EDUKASI \\ ISSN 1979-8598 e-ISSN: 2655-8378 \\ http://journal.binadarma.ac.id/index.php/jurnalbinaedukasi \\ Vol. 12, No. 1, Juni 2019, 16-30}

Pada tahap refleksi pada siklus II ini, peneliti dan guru kembali melakukan diskusi untuk mengevaluasi pelaksanaan siklus II baik pertemuan pertama maupun pertemuan kedua. Hal ini peneliti dan guru lakukan untuk mengetahui apakah pembelajaran PKn dengan menggunakan model pembelajaran PKn sudah berjalan dengan baik dan dapat meningkatkan hasil belajar siswa pada mata pelajaran PKn. Beberapa refleksi pada siklus II yakni:

a) Observasi terhadap guru dalam melaksanakan aspek-aspek dalam model pembelajaran scramble menunjukkan bahwa guru dan siswa sudah mampu menerapkan model pembelajaran scramble pada mata pelajaran PKn.

b) Siswa melaksanakan tugas dengan baik. hal tersebut dapat dilihat bahwa siswa sudah mampu mencocokkan antara lembar/kartu soal dengan lembar/kartu jawab dengan baik.

c) Penelitian tindakan kelas atau PTK dinyatakan berhasil karena telah memenuhi kriteria keberhasilan yaitu nilai rata-rata siswa berdasarkan hasil tes evaluasi meningkat dari siklus I ke siklus II yaitu 68,82 menjadi 82,94 .

d) Selain itu persentase ketuntasan hasil tes evaluasi siswa juga meningkat dari 70,59\% menjadi 88,24\% sehingga ketuntasan belajar siswa dalam satu kelas telah memenuhi Kriteria Ketuntasan Minimal (KKM) mata pelajaran PKn yakni 75. Pada siklus II kriteria keberhasilan yang ditetapkan peneliti telah tercapai yakni mencapai $88,24 \%$ dari jumlah total siswa.

Berdasarkan hal tersebut di atas dapat diketahui bahwa penggunaan model pembelajaran scramble pada mata pelajaran PKn dapat meningkatkan hasil belajar PKn siswa kelas V SD Negeri 13 Muara Kuang Hal tesebut ditunjukkan dengan meningkatnya rata-rata hasil belajar siswa. Selain itu jumlah siswa yang mencapai KKM juga meningkat.

Pada observasi awal kegiatan pembelajaran yang dilakukan masih berpusat pada guru dan siswa masih kurang antusias dalam pembelajaran di dalam kelas karena kegiatan yang dilakukan siswa yaitu mencatat materi, mengerjakan LKS, dan mengerjakan tugas yang diberikan oleh guru. Pelaksanaan model pembelajaran scramble berhasil meningkatkan hasil belajar PKn pada siswa kelas V SD Negeri 13 Muara Kuang. Model pembelajaran scramble dapat digunakan sebagai solusi bagi siswa dapat belajar dengan efektif karena pembelajaran yang dilakukan akan menciptakan siswa yang aktif sehingga membuat siswa dapat berpikir kritis. Pembelajaran yang menggunakan model pembelajaran menjadikan guru dapat merancang bahan-bahan pembelajaran yang sesuai dengan tujuan pendidikan. Hal tersebut sesuai dengan pendapat Joyce dan Weil (Uno, 2012: 219) yang menyatakan bahwa model pembelajaran merupakan suatu rencana atau pola yang dapat digunakan untuk membentuk kurikulum (rencana pembelajaran jangka panjang), merancang bahan-bahan pembelajaran, membimbing pembelajaran di kelas atau yang lain. 


\section{JURNAL ILMIAH}

BINA EDUKASI

ISSN 1979-8598 e-ISSN: 2655-8378

$\frac{\text { http://journal.binadarma.ac.id/index.php/jurnalbinaedukasi }}{\text { Vol. 12, No. 1, Juni 2019, 16-30 }}$

Menurut Shoimin (2016: 166) scramble merupakan model pembelajaran yang mengajak siswa untuk menemukan jawaban dan menyelesaikan permasalahan yang ada dengan cara membagikan lembar soal dan lembar jawaban yang diserta dengan alternatif jawaban yang tersedia. Model pembelajaran scramble dilaksanakan di kelas V SD Negeri 13 Muara Kuang yang berjumlah 17 siswa. pembelajaran telah dilaksanakan sesuai tahapan pelaksanaan dalam penelitian tindakan kelas yaitu perencanaan, pelaksanaan tindakan, observasi dan refleksi. Penelitian yang telah dilaksanakan di Kelas V SD Negeri 13 Muara Kuang berjalan dengan baik. Rangkaian penelitian tindakan kelas dilaksanakan dalam 2 siklus yang masing-masing siklus terdiri dari 2 pertemuan. Nilai rata-rata siswa dan persentase jumlah siswa yang mencapai KKM ( $\geq 65$ ) meningkat setelah dilaksanakan tindakan pada siklus I dan siklus II.

Nilai rata-rata hasil belajar PKn pada pra siklus sebersar 50,59 dengan jumlah siswa yang memnuhi KKM yakni 2 siswa atau setara dengan 11,76\% dari jumlah total siswa. Setalah dilaksanakan siklus I, nilai rata-rata hasil belajar PKn meningkat menjadi 68,82 dengan jumlah siswa yang memenuhi KKM yakni 12 siswa atau setara dengan 70,59\% dari jumlah total siswa. Siklus II dilaksanakan karena kriteria keberhasilan dari peneliti belum terpenuhi. Nilai rata-rata hasil belajar PKn pada siklus II meningkat kembali menjadi 82,94 dengan jumlah siswa yang memnuhi KKM yakni 15 siswa atau setara dengan 88,24\%. Hal tersebut menunjukkan bahwa pembelajaran PKn yang menggunakan model pembelajaran scramble dapar meningkatkan hasil belajar kognitif siswa pada mata pelajaran PKn siswa kelas V di SD 13 Muara Kuang.

Pembelajaran PKn dengan menggunakan model pembelajaran scramble menjadikan siswa aktif dalam pembelajaran di kelas maupun diskusi kelompok bersama teman. Hal tersebut sesuai dengan pendapat Asih (2013: 33) model pembelajaran memiliki dampak instruksional dan dampak pengiring pada siswa. Model pembelajaran scramble juga dapat melatih fokus siswa karena telah disediakan alternatif jawaban yang diacak susunannya. Pendapat tersebut didukung oleh Kawuryan (2014:32) yang menyebut bahwa model pembelajaran scramble akan menarik perhatian siswa karena siswa diharapkan mampu menyusun istilah kunci jawaban yang sudah diperkenalkan. Adanya lembar/kartu soal dan lembar/kartu jawab, membuat model pembelajaran scramble berbeda dengan model pembelajaran yang lain.

\section{SIMPULAN}

Berdasarkan hasil penelitian dan pembahasan, dapat disimpulkan bahwa hasil belajar kognitif PKn dengan materi keputusan bersama siswa kelas V SD Negeri 13 Muara Kuang dapat meningkat karena pembelajaran yang dilaksanakan menggunakan model pembelajaran scramble. Langkah-langkah dalam model pembelajaran scramble dapat berjalan dengan baik. 


\section{JURNAL ILMIAH \\ BINA EDUKASI \\ ISSN 1979-8598 e-ISSN: $2655-8378$ \\ http://journal.binadarma.ac.id/index.php/jurnalbinaedukasi \\ Vol. 12, No. 1, Juni 2019, 16-30}

Hal tersebut ditunjukkan dengan pelaksanaan langkah-langkah pada model pembelajaran scramble yang telah dilaksanakan secara keseluruhan. Sehingga hasil belajar kognitif siswa kelas V SD Negeri 13 Muara Kuang dapat meningkat. Hal tersebut ditunjukkan dengan peningkatan nilai rata-rata kelas pada pelaksanaam pra siklus yakni 50,59 meningkat di siklus I menjadi 68,82 serta meningkat kembali pada siklus II menjadi 82,94.

Peningkatan juga terjadi pada jumlah siswa yang nilainya memenuhi KKM (75) yaitu pada pra siklus hanya 2 siswa yang tuntas atau 11,76\% meningkat di siklus I menjadi 12 siswa atau 70,59\% dan meningkat kembali di siklus II menjadi 15 siswa atau 88,24\%. Peningkatan hasil belajar kognitif siswa kelas V SD Negeri 13 Muara Kuang dikarenakan guru menggunakan model pembelajaran scramble sehingga menjadikan siswa mampu mengerjakan soal dengan mudah karena sudah tersedia alternatif jawaban.

\section{DAFTAR PUSTAKA}

Arikunto, S. (2006). Prosedur Penelitian: Suatu Pendekatan Praktik (Edisi Revis VI). Jakarta: Rineka Cipta.

Arikunto, S. (2015). Penelitian Tindakan Kelas. Jakarta: Bumi Aksara.

Asih, R. (2013). Peningkatan Kualitas Pembelajaran PKn melalui Model Pembelajaran Scramble Bebasis Powerpoint pada Siswa Kelas VA SDN Bendan Ngisor Kota Semarang. Skripsi Sarjana, tidak diterbitkan, Universitas Negeri Semarang, Semarang.

Kawuryan, S.P. (2014). Panduan Praktikum: Pengembangan Pendidikan IPS SD. Yogyakarta: FIP UNY.

Muslich, M. (2007). KTSP: Pembelajaran Berbasis Kompetensi dan Kontekstual.Jakarta: Bumi Aksara.

Purwanto. (2009). Evaluasi Hasil Belajar. Yogyakarta: Pustaka Belajar.

Shoimin, A. (2016). 68 Model Pembelajaran Inovatif dalam Kurikulum 2013. Yogyakarta: ArRuzz Media.

Sugiyanto, H. (2009). Model-model Pembelajaran Inovatif. Surakarta: Yuma Pustaka

Sunarso, dkk. (2006). Pendidikan Kewarganegaraan: PKN untuk Perguruan Tinggi. Yogyakarta: UNY.

Uno, dkk. (2012). Menjadi Peneliti PTK yang Profesional. Jakarta: Bumi Aksara. 